\title{
Judicial disagreement need not be political: dissent on the Estonian Supreme Court*
}

\author{
Chris Hanretty
}

\begin{abstract}
I investigate the non-unanimous decisions of judges on the Estonian Supreme Court. I argue that since judges on the court enjoy high de jure independence, dissent frequently, and are integrated in the normal judicial hierarchy, the Estonian Supreme Court is a crucial case for the presumption that judicial disagreement reveals policy preferences. I analyse dissenting opinions using an ideal point response model. Examining the characteristics of cases which discriminated with respect to the recovered dimension, I show that this dimension cannot be interpreted as a meaningful policy dimension, but instead reflects disagreement about the proper scope of constitutional redress.
\end{abstract}

The study of apex courts - courts at the top of the judicial system of a country, whether formally part of that system or are separate constitutional courts - is an increasingly important part of the study of the politics generally. To some extent, this is a result of simple numerical growth in the number of apex courts in democratic systems (Romeu, 2006). Countries which democratized in the early nineteen-nineties all opted to establish courts to review the constitutionality of legislation with reference to constitutions embodying a

\footnotetext{
* This research was funded by a grant from the Nuffield Foundation, which I gratefully acknowledge.
} 
variety of important human rights. (That is, no country was sufficiently inspired by the United Kingdom to attempt a form of political constitutionalism: Bellamy (2007)). In each of these countries, there has been a struggle for constitutional justice (Schwartz, 2000) - and in some countries, this struggle has been more arduous than in others.

In the process of establishing such apex courts, institutional designers had to make a number of different choices. One important choice was whether or not to permit the publication of dissenting opinions: opinions which disagree with the outcome or disposition proposed by the majority (or in rarer cases a plurality) of the court. Amongst countries which drew up constitutions following the end of the second world war, the trend was against the publication of dissenting opinions. Thus, the Italian and French Constitutional Courts do not issue dissenting opinions, but only brief and often gnomic decisions of the court. Countries which democratised later - even countries which in other aspects of institutional design closely followed French and Italian models - tended to permit dissenting opinions. It is this pattern which has been followed by most countries in Central and Eastern Europe.

There are good reasons for banning dissent if one is concerned about a reputation for judicial impartiality. There is a strong presumption, derived from the study of American courts, that judges are little more than "legislators in robes" (Shepsle and Bonchek, $1997,418)$, and that this is particularly true for apex courts. Analyses of dissenting opinions outside of the United States have tended to confirm this general impression (Alarie and Green, 2007; Hanretty, 2012; Voeten, 2008). Where analyses have not revealed a political element to judicial disagreement, it has been because judicial disagreement does not express any particular substantive element at all, but rather a (differentially distributed) propensity to disagree per se (Hanretty, 2013).

The purpose of this article is to demonstrate that it is possible to find dissent on an apex court which is structured by a substantively interesting particular latent dimension, where that latent dimension is not itself political. Specifically, I find that dissent on the 
Estonian Supreme Court is characterised by disagreements over plaintiff-friendliness which cannot be reduced to disagreements about left-right political issues, and which are related to judges' background in particular areas of law.

In the following section, I discuss some of the literature on judicial behaviour, and why there is a strong expectation that patterns of judicial disagreement should be political in nature. I then go on to describe the Estonian Supreme Court; its composition; its caseload; and the types of dispute which it is called on to adjudicate. I analyse dissents as if they were expressions of sincere voting along a single policy dimension, and then analyse the cases which discriminte with respect to this recovered dimension. Through quantitative and qualitative analysis of these cases, I argue for an interpretation of the latent dimension as separate plaintiff-friendly judges from all other judges, and argue that this does not signify 'political' judging. I close by reflecting on the reasons why the Estonian Supreme Court is exceptional in this regard.

\section{Why expect political judging?}

First, there is a strong presumption that judges are policy-seekers. This view is most prevalent in the United States, where "the issue of what drives judges is largely settled" (Helmke and Sanders, 2006, 867), and where sets of measurements of judicial preferences along the left-right dimension (Martin and Quinn, 2002) are to judicial politics what estimates of policy positions from manifestos are to the study of party politics. However, the claim that judges are policy-seekers with respect to the left-right dimension has also been made for judges on the French Conseil Constitutionnel and German Bundesverfassungsgericht (Hönnige, 2009), the Italian Corte Costituzionale (Dalla Pellegrina and Garoupa, 2013), and the Spanish and Portuguese Constitutional Tribunals (Hanretty, 2012). The claim that judges are policy-seekers with respect to other dimensions, in particular the centre-periphery dimension, has also been made for the European Court 
of Justice (Malecki, 2012) and the European Court of Human Rights (Voeten, 2008).

Second, because of this strong presumption, where observable decisions do not warrant inferences about judges' policy preferences, this is often assumed to be the result of considerable constraints on judges' action, which may result either from the threat of policy reversal, or the threat of removal from office or non re-appointment. In particular, judges may fear the threat of reversal by a notionally sovereign Parliament (Hanretty, 2013), or the threat of non-compliance on the part of other courts within the normal judicial system (Garoupa and Ginsburg, 2012), or the threat of removal from office (laryczower et al. (2002) and, to some extent, Basabe-Serrano (2012)), or simply have a strong aversion to expressing disagreement (Hayakawa, 1964). All of these different explanations for a lack of disagreement can be framed within a general theory of judicial motivation (Helmke and Sanders, 2006).

Third, because there is a presumption that judges are policy-seekers whose ideal points are made manifest through their observable decisions except when institutional features mitigate against the expression of disagreement, a case study which shows that judges do not seek policy even where they have the opportunity to do so, has a value which is greater than the value of a merely accurate description of judicial behaviour in a particular country. In particular, a case study is valuable where, as I shall go on to argue, features of the case suggest that it is a crucial case, one where policy-seeking behaviour is most likely.

\section{Factors exacerbating/inhibiting political judging}

In this section, I outline four factors which tend to exacerbate/inihibit political judging, understood in the sense of policy-seeking voting: de jure/de facto judicial independence, the court's position within the legal and political system, norms of dissent, and legal culture. 
The first factor is the degree of judicial independence, considered either in de jure or de facto terms. The argument is that judges normally wish to vote sincerely for their policy preferences, but also wish to avoid sanctions from governments that would react negatively to a sincere vote. Consequently, since systems where judges enjoy a high degree of independence from government are systems where governments have fewer or less severe mechanisms for sanctioning judges, such systems should see higher levels of political judging. Although some scholars define the 'sanctioning cost' restrictively to include only the expected cost of sanctions from the incumbent government, incoming governments occasionally show themselves to have long memories. Although the precise nature and strength of the link between de jure and de facto judicial independence is unclear (Hayo and Voigt, 2007; Ríos-Figueroa and Staton, 2012), systems with high levels of both ought to have high levels of political judging, other things being equal.

The second factor is the position of the court within the legal and political system. Courts, and a fortiori individual judges, care about the court's perceived legitimacy. This may either be their legitimacy as perceived by society at large (Gibson et al., 1998), or by other judicial organs. Thus, judging in US state courts and federal district courts is characterised less by policy-seeking than judging in the Supreme Court, because judges lower in the hierarchy must anticipate the potential costs of their decision being reversed (Songer et al., 1994). This argument can be extended to some apex courts, since constitutional courts in the Kelsenian model often face competition from courts at the top of the normal judicial hierarchy (Garoupa and Ginsburg, 2012).

Third, we must consider norms of dissent within a particular legal system. In some systems, or at some points in time in some systems, there is a strong norm against dissenting opinions. In extremis, this can lead to dissenting opinions being forbidden, as is the case with a number of Kelsenian constitutional courts, and the Irish Supreme Court when hearing constitutional cases. In less extreme scenarios, this may lead to courts where dissent is too limited to permit inferences about judges' ideal points, or where 
the propensity to dissent itself is the only signal amongst the noise (Hanretty, 2013). Of course, to some extent a strong norm against dissent may be a post-hoc rationalisation, due to the persistent risk of sanctions against judges who take iconoclastic stances. It is, however, more difficult to argue that celebration of a pro-dissent norm is a rationalisation of a low risk of sanctions.

The fourth and final factor concerns the legal culture, or the family of law practised. It has sometimes been argued that common law systems, since they allow greater judicial discretion, are more prone to dissent. However, it is not clear whether this argument is really an argument about features inherent to the common law system, or rather an argument about features inherent to its great contrast, code law systems. Certainly, the great debate over legal families has not really clarified much, and now rather disabuses the notion that legal families structure all aspects of law (Siems, 2007).

Having outlined a number of factors which might inhibit or exacerbate political judging, I can now turn to the Estonian context, and make the case for considering it as a crucial case for the view that judges may generally be considered as policy-seekers.

\section{The Estonian context}

The Estonian Supreme Court, or Riigikohus, is the highest court in Estonia. It functions both as a constitutional court and as a court of cassation. In this respect it differs from other apex courts in Central and Eastern Europe, which are typically dedicated constitutional courts. It resembles more closely courts in common law legal systems.

This is because the Supreme Court is the successor to the original Supreme Court established in October 1919 as a court of cassation only, following the Estonian war of independence. Although the court was abolished following Soviet occupation, it was reconstituted with the ratification of the Estonian constitution in June 1992 (Supreme Court of Estonia, 2011, 28-30). There is, therefore, some sense in which the Supreme 
Court antedates the Kelsenian trend for separate constitutional courts.

The internal structure of the court reflects the dual nature of the court. There are three 'ordinary' chambers (Criminal, Civil, and Administrative), and one slightly larger Constitutional Review chamber. The court hears more controversial cases, including more controversial constitutional review cases, en banc.

The Court consists of nineteen judges, including the Chief Justice. According to Article 150 of the constitution, the Chief Justice is appointed by the Parliament upon the proposal of the President of the Republic; and ordinary members of the court are in turn appointed by the Parliament upon the proposal of the Chief Justice. The Parliament, after a report by its Constitution Committee, decides by simple majority whether or not to appoint the nominated judge. Most candidates are approved by substantial majorities.

Judges are appointed for life (Art. 147, $\S 1$, Constitution), and may not be removed except by a court decision. Judges have retired from the court; have left the court either for personal reasons (Tiit Kollom); and have left in order to to take up posts in other institutions (Julia Laffranque and Uno Lōhmus both became judges at the European Court of Human Rights).

Requirements for eligibility are set out in Art. 47 (general) and 52 (Supreme Courtspecific) of the Courts Act 2002, according to which judges must be "experienced and recognized lawyers" (Art. 52), and may not be members of a political party, or members of Parliament. Despite the requirement that nominees be experienced and recognized lawyers, the average age of the court is considerably lower than other comparable courts in the region. This results in part from a ban on nominees older than 67 years old. In part it seems to result from a preference for younger nominees: Villu Kōve and Ivo Pilving were both in their early thirties when appointed.

Cases $^{1}$ arrive at the Court by one of five routes (Maveety and Pettai, 2005, 94,112). First, cases may be appealled from inferior courts. Second, legislation may be referred to the court by the President of the Republic. Third, legislation may be referred to the court 
by the Legal Chancellor, an ombudsman-like figure who is non-partisan, but who may be petitioned by members of parliament. Fourth, international treaties may be referred to the court by the Riigikogu. Fifth, following the passage of the 2002 Constitutional Review Court Procedure Act, individuals or political parties engaged in electoral disputes may also petition the court.

Dissenting opinions on the court (eriarvamus) are permitted by $\S \S 26-27$ of the Court's Rules of Procedure. Once a rapporteur has been assigned a case, s/he will draw up a list of itemized questions which must be answered in order to dispose of the case, along with an indication of position the rapporteur believes should be taken. These questions, and potential answers, are discussed and voted upon by judges hearing the case, following which members dissatisfied with the majority judgement are given time to file a dissenting opinion. Dissenting opinions are not just restricted to the Supreme Court, but are present throughout the court system.

\section{The Estonian Supreme Court in perspective}

Given the factors identified above as exacerbating or inhibiting political judging, should we expect political judging on the Estonian Supreme Court? I would suggest that we should. This is because the court enjoys a high degree of independence (both de jure and de facto); because the court operates at the top of the judicial hierarchy; because there is no anti-dissent norm. Only in one respect - the prevailing legal culture - should we expect lower levels of political judging due to limited judicial discretion.

Consider first the degree of independence of the court. Ríos-Figueroa and Staton (2012) consider twelve different measures of de facto and de jure independence. Of these, four (de jure and de facto measures from Feld and Voigt (2003); de facto measures from Howard and Carey (2003) and Keith (2002)) deal explicitly with the highest court. For these measures, subsetting (1) to the years 1994 to the latest year for which 
data was available for each country, and (2) to the countries of the EU27, plus the USA, Estonia ranked 12th (USA: 11th); joint 11th (USA: 13th); joint 24th (USA: joint 1st with 23 other countries); and joint 17th (USA: 22nd) respectively. Thus, if levels of (de jure and de facto) judicial independence on the Supreme Court of the United States are sufficient for political judging, they ought also to be sufficient for the Estonian Supreme Court.

Second, because the Estonian Supreme Court operates at the top of the judicial hierarchy, it does not face the problems of having to moderate in order to secure co-operation from parallel courts. Only by considering the position of the Estonian Supreme Court vis-á-vis either the European Court of Justice or the European Court of Human Rights as analogous to the position of circuit courts vis-á-vis SCOTUS could one argue that political judging in the Estonian Supreme Court might be inhibited; but this argument (a) grossly exaggerates the role of the ECJ vis-á-vis national courts, and (b) would in any case have to be pursued carefully, for in general, agents faced with multiple principals find it easier to 'shirk'.

Third, there is a strong awareness of the benefits of dissenting opinions, and this applies throughout the judicial hierarchy. This is rare throughout Central and Eastern Europe: Lithuania and Slovakia did not initially permit the publication of dissenting opinions; and Latvia and Hungary permit dissenting opinions only in their constitutional courts. Judges on the Estonian Supreme Court have published strong arguments in favour of the dissenting opinion (Laffranque, 2003; Kergandberg, 1998). There is no evidence to suggest that there is a general norm against authoring dissenting opinions.

The fourth and final factor concerns the legal family. Only in this respect might we see reasons for not expecting political judging. Estonia inherited a socialist legal system, and has gradually been moving towards, or perhaps returning to, a German-inspired legal system based around extensive definition of terms (Luts, 2001). To the extent that such a legal system might be thought antithetical to political judging (and Hönnige (2009) suggests it is not), we might expect either such low levels of dissent as to make 
impossible the drawing of reliable inferences concerning judges' ideal points, or the confining of such disagreement as exists to minor matters.

\section{Data and analysis}

Whilst the previous section adumbrated certain data relating to the Estonian Supreme Court, in this section I outline the characteristics of the data I use on dissenting opinions, and how this data can be analysed using a 'vanilla' ideal-point model. Only in the next section do I show that the results from this ideal point model, whilst substantively interesting, do not support an interpretation of the recovered dimension as a 'political' dimension.

The data I use cover the period from 1993 until the end of 2010. Specifically, I examine the 120 cases that featured at least one dissenting opinion. I concentrate on dissenting cases only because information on unanimous opinions provides no information as to the different stances (ideological or otherwise) of the judges, absent a strong theory about what constitutes, for example, a 'liberal' or 'conservative' decision.

The average number of cases involving dissent per year was around 7, which means that given the Court's average annual caseload of around 367 cases only around $1.7 \%$ of cases featured a dissent. This percentage seems to be increasing over time, though it is not clear whether this apparent trend results from lower levels of dissent in the Court's early years, or whether we can expect rates of dissent to continue growing.

This percentage figure is calculated on the basis of all cases heard by the Court in a given year, although this is somewhat misleading in that most dissents are given in the much smaller number of constitutional review cases or cases heard en banc. Of the 120 cases featured here, only 39 were heard in three-judge panels.

With two exceptions (Peeter Vaher and Märt Rask), all judges who have served on the Court have dissented at some point in time. Three judges (Rait Maruste, Herbert 
Lindmäe, and Tiit Kollom) dissented only once, though Tiit Kollom only heard a very few cases on the court before resigning for family reasons. The most frequent dissenters (Eerik Kerkandberg, Jüri Pōld and Jaak Luik) have all written or joined in with more than twenty-five dissents.

This data can be put in to a data matrix, which has dimension $i=120$ by $j=27$, and which represents a notional super-court, composed of all the judges. The entries in this data matrix may either indicate that in case $i$ judge $j$ concurred with the majority $\left(y_{i j}=1\right)$, dissented from the majority ( $y_{i j}=0$ ), or did not participate (i.e., data is missing).

I analyse this data using item response methods. Item response methods can be used wherever we believe that binary or ordinal responses to a battery of items can be modelled as a function of an underlying trait, or position along a latent dimension, with due allowance given for the position which those items have along that same dimension, and the degree to which those items discriminate between those responding to our items who have otherwise similar positions along that dimension. The most well known application of this technique to judicial politics comes from the United States Supreme Court, where the dissenting behaviour of US Supreme Court Justices has been analysed using these techniques to generate estimates of judge's 'ideal points' along a latent dimension running from left to right, and commensurable in principle with the left right dimension that structures US politics.

While such techniques are bound to produce a 'position' along a latent dimension for each judge, there is no guarantee that (a) this method of analysing dissent will produce results will fit well the observed data; or (b) that this position, or the underlying latent dimension, will have a substantively meaningful interpretation. Thus, in an analysis of voting behaviour in the British House of Lords, Hanretty (2013) found that analysing the House of Lords in this data neither fitted well the data, nor gave a substantively interesting interpretation: positions along the recovered latent dimension simply tracked judges' propensity to dissent. 
Consequently, the item response techniques used here are a necessary but not sufficient part of the analysis. Although it is important to demonstrate that these techniques produce estimates that fit the observed data, a second stage of qualitative analysis must be carried out in order to identify the meaning of these numbers.

With these qualifications out of the way, we can proceed to specifying the model more formally. I follow the notation before, where $i$ indexes cases, $j$ judges, and where $y_{i j}$ is the judge j's vote on case i. Let each judge's position along the latent dimension be $\theta_{j}$.

Let each case have two parameters - a location parameter, $\alpha_{i}$, and a discrimination parameter, $\beta_{i}$. Of these two, the discrimination parameter is the more important for our analysis. Cases with a discrimination parameter which is significantly different from zero will be cases that separate otherwise-close judges, and which therefore offer an insight into the meaning othe recovered dimension.

Using this notation, we may model the probability of voting with the majority is

$$
\operatorname{Pr}\left(y_{i j}=1\right)=F\left(-\alpha_{i}+\beta_{i} \theta_{j}\right)
$$

where $F$ is the normal cumulative distribution function. Thus, for cases with a positivelyvalued $\beta$, judges with larger values of $\theta$ will be more likely to concur; conversely, for cases with a negatively valued $\beta$, judges with larger values of $\theta$ will be less likely to concur.

We can produce estimates of this model given an estimation technique, and certain constraints on some of the parameters. I estimate this model using Monte Carlo Markov Chain (MCMC) models. ${ }^{2}$ These models require additional checks to ensure that our estimates of the different parameters have converged. Here, I base my estimates on 1750000 iterations preceded by 250000 burn-in iterations, and thinned every 250 iterations. The model run came close to convergence, since the value of Geweke's diagnostic for the parameters on judges' ideal points had a mean of 0.11 with $95 \%$ quantiles in 
the range $[-1.93,2.38]$, close to the critical range of \pm 1.96 .

Constraints must be imposed on some of the parameters, because the likelihood of the model is unchanged if all of the estimates are either shifted by a particular constant, or if they are scaled by some constant. I therefore normalize the ideal points to have zero mean and unit standard deviation. This deals with the problem of scale invariance, but leaves the problem of rotational invariance. Thus, there is no information within the model which tells us which end of the recovered dimension corresponds to a particular substantively interesting aspect of judging. This is why we must first begin with the recovered dimension before moving on to a qualitative analysis.

\section{[Table 1 about here.]}

A number of statistics concerning the overall fit of the model are presented in Table 1. As is normal for models of this type, the percentage of decisions 'predicted' correctly is quite high, at 86.34 , but this averages out greater predictive accuracy for concurring opinions and poorer predictive accuracy for dissenting opinions. A null model which only predicted concurrences would still predict a high number of decisions correctly. An overall assessment of the fit of the model is given by the geometric mean probability, or GMP. The GMP ranges between zero and one; values of 0.5 indicate that the predictive ability of the model is comparable to a coin toss. Here, the value of 0.74 indicates that the model fits the data reasonably well.

[Figure 1 about here.]

Of course, we are estimating this model to also extract information about the location of judges along some idealized dimension of judicial decision-making rather than to retrodict decisions. Figure 1 plots the location of each of the judges along the recovered dimension, and their associated $95 \%$ credible intervals. Credible intervals are larger for judges who heard relatively few cases. Thus, considerable uncertainty surrounds the 
placement of Tiit Kollom, who only heard a few cases before retiring from the Court for family reasons.

\section{How to interpret the recovered dimension}

In the previous section, I suggested that judges on the Estonian Supreme Court could be arrayed on a single, 'latent', dimension, which could be used to retrodict a high number of decisions in cases involving dissent. However, the fact that we can array judges on such a latent dimension does not mean that this dimension has any substantive meaning that we can readily interpret. It might merely be a statistical artefact.

In this section, I shall discuss two possible interpretations of the recovered dimension: that it reflects the identity and interests of those involved in appointing each justice to the court; and that it reflects judges' different preferences over the outcomes of legal disputes, in particular 'plaintiff-friendliness'.

\section{Appointment offers no guide}

One important way of testing for political judging is to test for a correlation between the position of the actor or actors who appointed each judge, and some outcome or measure attributable to that judge. Concerning outcomes, Hönnige (2009) has tested the link between the ascribed political position of the median judge on the French and German Constitutional Courts, and the likelihood of an ideologically distant or proximate government succeeding in those court. Concerning measures, the debate in the United States about the link between the left-right positions of Presidents and the positions of their nominees concerns not whether there is such a link, but whether it holds (1) across all appointments or only over distal appointments (Krehbiel, 2007); and (2) across time, as nominees drift (Hönnige, 2009).

Here, I examine the correlation between the estimated ideal points of judges, and 
the left-right positions of the appointing actors. Because the direction of the recovered dimension is arbitrary, what matters is the significance of the correlation: to the extent that there is a significant correlation, we presume that the relationship is correctly signed. When considering the left-right position of the appointing actors, we may either consider, for Chief Justices, the left-right position of the appointing President, and assume that this is transmitted faithfully through the subsequent nominations of Chief Justices appointed by that President, or the left right position of the median legislator at the time of each appointment. $^{3}$

I do not consider more sophisticated models of appointment, because there is very little evidence for any kind of relationship, even an attenuated one. The correlation between the left-right position of the median legislator and the position on the recovered dimension of each judge is small and insignificant $(r=-0.04, p=0.86)$. The correlation between the left-right position of the appointing President (for Chief Justices) or the appointing Chief Justice (ascribed the position of the appointing President) and the same judge positions is also small and insignificant $(r=-0.11, p=0.58)$.

\section{Liberal and conservative outcomes}

A second approach to demonstrating 'political judging' is to code case outcomes as either being left-wing or right-wing outcomes: in North American terminology, as liberal or conservative outcomes. As Maveety and Pettai $(2005,113 n 14)$ note, such exercises are difficult because "it is [not] transparently obvious how to code a 'liberal' or a 'conservative' judicial response to various issues". Nevertheless, some tentative approaches have been made.

Here, I have used information on the broad legal area, coded following the dictionary supplied by the Council of Europe's Venice Commission. For each of these legal areas, I have indicated whether a victory for the plaintiff would represent a liberal outcome. In this I have been guided by the practice not only of the US-specific Supreme Courts 
Database, but also the comparative common law High Courts Judicial Database. A full list of legal areas where victories for the plaintiff correspond to liberal, conservative and neutral outcomes is found in the Appendix. Some of these codings are more easily appreciated than others. Thus, the 'right for life' case area, in so far as it relates to abortion and end-of-life issues, is often associated with particular conservative religious worldviews about the sanctity of life. Conversely, the 'collective rights' and 'Social security' case areas are associated with a left-wing political philosophy which pursues redistribution through collective bargaining and a broad welfare state.

However, a number of codings rely on broad principles which are the result of common North American practice. Thus, whilst the content of a general right not to incriminate oneself is neither obviously 'left' or 'right', its coding as a 'liberal' case area (that is, a case area in which a victory for the plaintiff would indicate a liberal outcome) is based on the finding that 'liberal' judges in the United States tend to be more lenient towards those suspected of having committed crimes. Thus, to the extent that some of these codings are controversial, I trust that they are controversial for the same reasons that standard practice is controversial, not because of any additional element that I have added.

If case outcomes can be coded in this way, we may ask whether there is any relationship between the case outcome and the ideal points of the judges, as shown in Figure 1. One way of testing this is to cross-tabulate liberal outcomes against the 'handedness' of the majority on the court. A 'left-handed' decision is one where the majority of the court was to the left of the minority on the court. A 'right-handed' decision is simply the converse.

\section{[Table 2 about here.]}

As can be seen from Table 2, there is no strong relationship between the liberality or conservative character of a case outcome, and the 'handedness' of the majority. There are more 'conservative' outcomes in general, but the cell counts are almost exactly as we would expect given the marginal distributions $\left(\chi^{2}=0.02\right)$ 


\section{Plaintiff-friendliness}

If there is no relationship between the left-right positions of those who appointed the judges, and the positions of these judges, and if there is no relationship between the positions of the judges in the majority and the type of outcome delivered, what does explain the nature of the recovered dimension? Here, I argue that the single dimension which separates judges on the Supreme Court has to do with their orientation towards the arguments made by plaintiffs alleging infringement of their rights.

Specifically, I argue that judges towards the right-hand side of the recovered dimension (Pōld, Laffranque, Salmann, Koolmeister) are more likely to have come from an administrative law tradition, and are therefore more likely to evaluate claims of constitutional rights infringement not by challenging the presumed right, but by evaluating the proportionality of the government action. Conversely, those on the left hand side of the recovered dimension are much less likely to find that government action or legislative provisions are unconstitutional since in violation of constitutional rights.

\section{[Table 3 about here.]}

We can get a first approximation to this argument by examining some of the statistics on outcomes according to the identity of the winning party. Table 3 shows the identity of the winning party to the case, according to the 'handedness' of the majority on the court. The key difference is that, when judges in the right-hand side are in the majority, more than half of cases are won by plaintiffs. Only three-tenths of cases are won by plaintiffs when judges in the left-hand side are in the majority. These differences are significant at the $10 \%$ level $\left(\chi^{2}=5.82\right.$ on 2 d.f., $\left.p=0.05\right)$.

A second approximation comes from the positions of the judges according to the chamber in which they hear most cases. As should be evident from Figure 1, judges from the right hand side of the recovered dimension are much more likely to come from the administrative law chamber. The posterior probability that judges from the adminis- 
trative chamber are further to the right hand side of the recovered dimension than judges from any other chamber approaches $100 \%$.

Finally, the importance of this kind of plaintiff friendliness also emerges when examining particular cases. Here, I limit my analysis to all those cases which discriminated with respect to the recovered dimension (56 cases in total), and which have been translated in to English by the court.

The best example of plaintiff-friendliness concerns prisoners' access to web sites (RK 3-3-1-5-09). In this case, plaintiff Romeo Kalda argued that the refusal of the Tartu prison to ensure him access to the website of the Council of Europe Information Office in Tallinn, the parliament web-site, and the site of the Chancellor of Justice, constituted a violation of his right to public information found in $\S 44(1)$ of the Constitution. The majority of the court (drawn from the left-hand side of the recovered dimension) dismissed Kalda's appeal, finding that whilst the ban on internet access to these sites did constitute an infringement of Kalda's constitutional rights, the infringement was proportionate, insofar as it aimed at the objective of prevent misuse of the internet by prisoners, and insofar as alternatives (writing to the Council of Europe, obtaining documents on request) were available. The minority of the court (judges Anton, Koolmeister, Pōld, and Salmann) took the majority to task for failing to seriously examine the proportionality of the infringement - how viable were the alternatives? how realistic was the threat of misuse from allowing access to such sites? At one level, therefore, this case reveals a disagreement about the intensity of review when the proportionality of rights infringements is in question. At another, more simplistic level, this case reveals a difference in plaintiff-friendliness, in that plaintiffs are typically beneficiaries of demanding standards of proportionality.

Further evidence for these differences comes from a series of cases concerning provisions of the Traffic Act. The issue in these cases concerned whether sanctions given for traffic offences were of sufficient gravity that they would cease to be mere misdemeanour proceedings and would become proper hearings involving a right for the relevant indi- 
vidual to defend himself/herself. The majority of the court was reluctant to declare any part of the Traffic Act unconstitutional; the minority, mostly drawn from the Administrative Chamber, insisted that these sanctions very often touched on important constitutionally guaranteed rights such as the right to family life and the right to freedom of movement, and that the efficiency of driving licence administration was not to trump the rights of individuals to defend themselves.

In both of these examples, a minority of the court drawn from the right-hand side of the recovered dimension intervened on behalf of law-breakers. However, this plaintifffriendliness is not just restricted to plaintiffs of certain types. This same group of judges has also defended the property rights of collectives in re-nationalisation cases (RK 32-1-59-04), and in the process of defending businessman Tiit Veeber (RK 3-3-2-1-04), called for much stronger procedures to protect individuals who had secured a ruling from the ECHR that their rights had been violated (justices Pōld, Luik).

\section{Conclusion}

In this article I have demonstrated that there is a substantively interesting pattern of dissent on the Estonian Supreme Court which is not political in nature. Rather, it relates to differences between the judges about the proper way of evaluating the claims of plaintiffs, with judges on one side preferring to take plaintiffs' claims of rights infringements as valid on the face of it, and then establish the proportionality of the alleged infringement, and judges on the other side preferring to reject such claims.

By doing so, I have provided a counter-example to the common presumption that judicial disagreement is either conflictual and political, or minimal. I have also argued that this finding is not inert: there are good theoretical reasons for thinking that policyseeking judging ought to be present in Estonia.

Naturally, the question arises as to why policy-seeking judging is not present despite 
high levels of judicial independence and an appreciation of the dissenting opinion. One possible answer lies in the method by which judges are appointed. Two factors are important: the method of appointing as and when vacancies arise, and the involvement of the judiciary. I have argued elsewhere that multi-member appointments result in the creation of a package of appointments the median point of which is approximately 'balanced', but which is characterised by wide dispersion. By contrast, sequential appointments force appointing bodies to appoint each judge at a median point, and thus, since they cannot shift policy, prioritise quality.

Second, whilst the involvement of the judiciary has not led to depoliticisation in Italy, Bulgaria, or Romania, the degree to which appointments to the court are driven by merit rather than completion of a cursus honorum is, at least in comparison with countries like the United Kingdom, most admirable. It is difficult to foresee whether the current membership of the court will engage in more political behaviour as they enter their second or third decades on the court - but any test of this would at least have to part from the presumption that non-political judicial disagreement is a possible, if aberrant or fleeting condition. 


\section{A. Areas by outcome type}

'Liberal' case areas Victory for plaintiff in these areas treated as a liberal outcome. Criminal proceedings, Deprivation of liberty, Rights of the child, Consumer protection, Citizens of the European Union and non-citizens with similar status, Inviolability of communications, Right to a pension, Principle of the application of the more lenient law, Right to private life, Procedural safeguards, rights of the defence and fair trial, Freedom to choose one's profession, Right not to incriminate oneself, Prohibition of torture and inhuman and degrading treatment, Economic, social and cultural rights, Right to a sufficient standard of living, Right to be informed about the decision, Right to the environment, Freedom of opinion, Individual liberty, Right to paid legal assistance, Collective rights, Right to citizenship or nationality, Rights in respect of the audiovisual media and other means of mass communication, Freedom of the written press, Social security, Right to just and decent working conditions, Entitlement to rights, Equality

'Conservative' case areas Victory for plaintiff in these areas treated as a conservative outcome.

Right to participate in the administration of justice, Right to compensation for damage caused by the State, Market economy, Freedom of contract, Right to respect for one's honour and reputation, Right to administrative transparency, Right to property, Nationalisation, Freedom to work for remuneration, Arrangements for distributing the financial resources of the State, Commercial and industrial freedom, Expropriation, Taxation law, Rights of victims of crime, Right to life

'Neutral' case areas Victory for plaintiff in these areas treated as neither a liberal nor a conservative outcome. Elections and instruments of direct democracy, Scope of review, National rules, Civil law, Constitutional jurisdiction, Non-penal measures, Budgetary and financial aspects, Proportionality, Trial/decision within reasonable time, Crim- 
inal law, Reasoning, Vested and/or acquired rights, Municipalities, Right to information, Reasonableness, Civil proceedings, Certainty of the law, Ne bis in idem, Clarity and precision of legal provisions, Non-retrospective effect of law, European Charter of Local Self-Government of 1985, Access to courts, Nullum crimen, nulla poena sine lege, Foreigners, Legality, Rules of evidence, Employment, Privatisation, , Constitution, Nationals, Scope of application, Concept of constitutionality dependent on a specified interpretation, Right of access to administrative documents, Public judgments, Liability of judges, Supervision, Term of office of members, Electoral rights, Right to examine witnesses, Protection of personal data, Appointment of members, Double degree of jurisdiction, Rule of law, Hierarchy, Jurisdiction, Prohibition of arbitrariness, Scope, Language, In public law, Right of access to the public service, Right to work, Right to participate in public affairs, Right to be informed about the charges, National rules from other countries, Right to have adequate time and facilities for the preparation of the case, Concept of manifest error in assessing evidence or exercising discretion, Legal assistance and representation of parties, Correspondence, Legal persons, Presumption of innocence, End, Weighing of interests, Right to stand for election, Succession, Margin of appreciation, European Convention on Human Rights of 1950, Right of access to the file, 5.13.18, Hierarchy as between national sources 


\section{Notes}

${ }^{1}$ As distinct from disputes concerning the status of members of the Riigikogu or the Riigikogu's rules of procedure.

${ }^{2}$ Specifically, I use Simon Jackman's pscl package for R.

${ }^{3}$ Data for the left-right positions of legislators and presidents are taken from www. ParlGov .org. Lennart Meri is ascribed the left-right position of Pro Patria; Arnold Rüütel the position of the Estonian Centre Party (Eesti Keskerakond). 


\section{References}

Alarie, B. and Green, A. (2007). The reasonable justice: an empirical analysis of Frank lacobucci's career on the Supreme Court of Canada. University of Toronto Law Journal, 57(2):195-226.

Basabe-Serrano, S. (2012). Judges without robes and judicial voting in contexts of institutional instability: The case of Ecuador's Constitutional Court, 1999-2007. Journal of Latin American Studies, 44(01):127-161.

Bellamy, R. (2007). Political constitutionalism. Cambridge University Press.

Dalla Pellegrina, L. and Garoupa, N. (2013). Choosing between the government and the regions: An empirical analysis of the Italian Constitutional Court decisions. European Journal of Political Research, 52.

Feld, L. P. and Voigt, S. (2003). Economic growth and judicial independence: crosscountry evidence using a new set of indicators. European Journal of Political Economy, 19(3):497-527.

Garoupa, N. and Ginsburg, T. (2012). Building reputation in constitutional courts: Party and judicial politics. Arizona Journal of International and Comparative Law.

Gibson, J. L., Caldeira, G. A., and Baird, V. A. (1998). On the legitimacy of national high courts. American Political Science Review, pages 343-358.

Hanretty, C. (2012). Dissent in Iberia: The ideal points of justices on the Spanish and Portuguese Constitutional Tribunals. European Journal of Political Research.

Hanretty, C. (2013). The decisions and ideal points of British Law Lords. British Journal of Political Science, 1(1):1-3.

Hayakawa, T. (1964). Civil liberties in the Japanese Supreme Court. In Schubert, G., editor, Judicial Behavior: A Reader in Theory and Research. Rand McNally, Chicago. 
Hayo, B. and Voigt, S. (2007). Explaining de facto judicial independence. International Review of Law and Economics, 27(3):269-290.

Helmke, G. and Sanders, M. S. (2006). Modeling motivations: A method for inferring judicial goals from behavior. Journal of Politics, 68(4):867-878.

Hönnige, C. (2009). The electoral connection: How the pivotal judge affects oppositional success at European constitutional courts. West European Politics, 32(5):963-984.

Howard, R. M. and Carey, H. F. (2003). Is an independent judiciary necessary for democracy. Judicature, 87:284.

laryczower, M., Spiller, P. T., and Tommasi, M. (2002). Judicial independence in unstable environments, Argentina 1935-1998. American Journal of Political Science, pages $699-716$.

Keith, L. C. (2002). Judicial independence and human rights protection around the world. Judicature, 85(4):194.

Kergandberg, E. (1998). Kohtuniku eriarvamusest. Õigus Teada, 24(4):6-7.

Krehbiel, K. (2007). Supreme Court Appointments as a move-the-median game. American Journal of Political Science, 51(2):231-240.

Laffranque, J. (2003). Dissenting opinion and judicial independence. Juridica International, 8.

Luts, M. (2001). Textbook of Pandects or new style of legislation in Estonia? Juridica International, 6:152-158.

Malecki, M. (2012). Do ECJ judges all speak with the same voice? evidence of divergent preferences from the judgments of chambers. Journal of European Public Policy, 19(1):59-75. 
Martin, A. D. and Quinn, K. M. (2002). Dynamic ideal point estimation via Markov Chain Monte Carlo for the US Supreme Court, 1953-1999. Political Analysis, 10(2):134-153.

Maveety, N. and Pettai, V. (2005). Government lawyers and non-judicial constitutional review in Estonia. Europe-Asia Studies, 57(1):93-115.

Ríos-Figueroa, J. and Staton, J. K. (2012). An evaluation of cross-national measures of judicial independence. Journal of Law, Economics, and Organization.

Romeu, F. (2006). The establishment of constitutional courts: A study of 128 democratic constitutions. Review of Law and Economics, 2(1):103-135.

Rosenberg, G. (2008). The hollow hope: Can courts bring about social change? University of Chicago Press.

Schwartz, H. (2000). The struggle for constitutional justice in post-communist Europe. University of Chicago Press.

Shepsle, K. and Bonchek, M. (1997). Analyzing politics: Rationality, behavior and institutions. New York.

Siems, M. (2007). The end of comparative law. Journal of Comparative Law, 2:133-150.

Songer, D. R., Segal, J. A., and Cameron, C. M. (1994). The hierarchy of justice: Testing a principal-agent model of Supreme Court-circuit court interactions. American Journal of Political Science, pages 673-696.

Supreme Court of Estonia (2011). The Supreme Court of Estonia. Available online, Tartu. English language booklet published by the Court.

Voeten, E. (2008). The impartiality of international judges: Evidence from the European Court of Human Rights. American Political Science Review, 102(4):417-432. 


\section{List of Figures}

1. Ideal points of justices . . . . . . . . . . . . . . 28 
Figure 1: Ideal points of justices

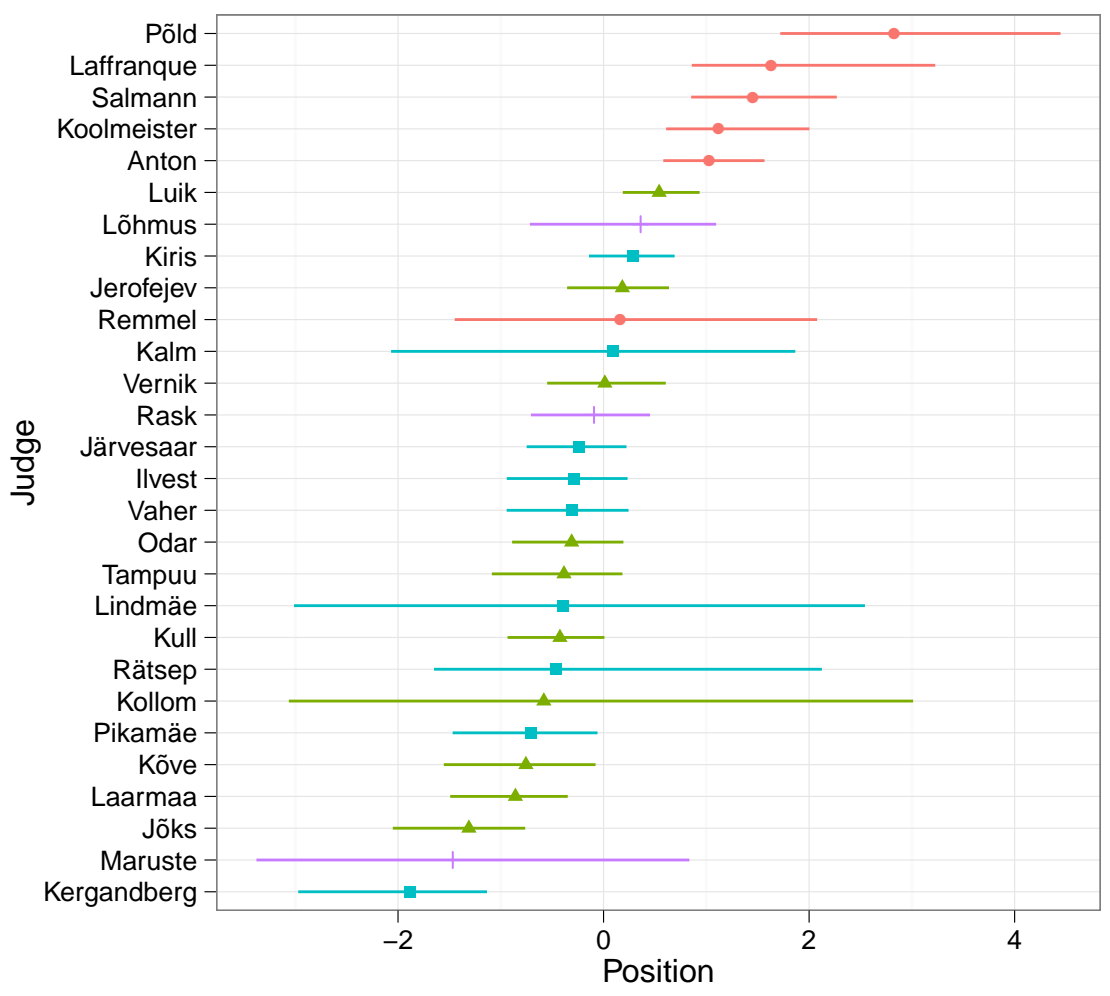

Chamber $\rightarrow$ Administrative $\rightarrow$ Civil $\rightarrow$ Criminal $\rightarrow$ President 


\section{List of Tables}

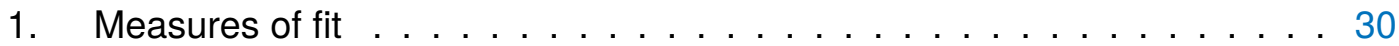

2. Liberal outcomes by majority . . . . . . . . . . . . . . . 31

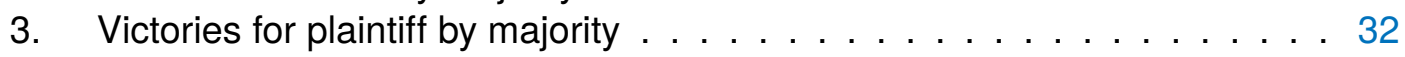


Table 1: Measures of fit

\begin{tabular}{lc}
\hline Item & Statistic \\
\hline Percentage correctly predicted & 86.34 \\
'Concurring' votes correctly predicted & 96.24 \\
Dissenting votes correctly predicted & 60 \\
Best-predicted judge & Rait.Maruste \\
(Percentage) & 100 \\
Worst-predicted judge & Tiit.Kollom \\
(Percentage) & 0 \\
Log-likelihood & -296.26 \\
GMP & 0.74 \\
\hline
\end{tabular}


Table 2: Liberal outcomes by majority

\begin{tabular}{lrc}
\hline & LHS & RHS \\
\hline Conservative & 13 & 22 \\
Liberal & 7 & 15 \\
\hline
\end{tabular}


Table 3: Victories for plaintiff by majority LHS RHS

\begin{tabular}{lrr} 
Respondent & 8 & 11 \\
Neither & 22 & 19 \\
Plaintiff & 13 & 33 \\
\hline
\end{tabular}

